ENTREPRENEURSHIP AND SUSTAINABILITY ISSUES

ISSN 2345-0282 (online) http://jssidoi.org/jesi/

2020 Volume 7 Number 3 (March)

http://doi.org/10.9770/jesi.2020.7.3(38)

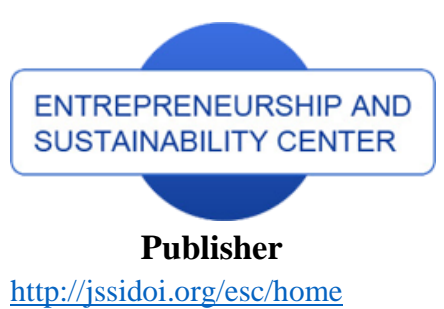

http://jssidoi.org/esc/home

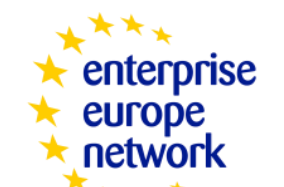

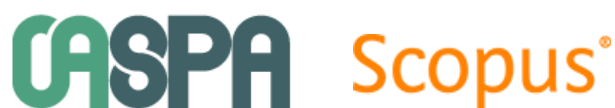

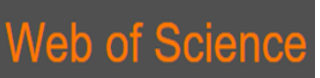

1 Clarivate

Analytics

\title{
AN ECONOMIC ANALYSIS OF AGRICULTURAL PRODUCTION FUNCTION ON THE PADDY FIELDS OF THAILAND
}

\author{
Sudawan Somjai ${ }^{1}$, Thitinan Chankoson ${ }^{2}$, Kittisak Jermsittiparsert ${ }^{3 *}$ \\ ${ }^{1}$ Graduate School, Suan Sunandha Rajabhat University, Bangkok, Thailand \\ ${ }^{2}$ Faculty of Business Administration for Society, Srinakharinwirot University, Bangkok, Thailand \\ ${ }^{3}$ Contemporary Peasant Society Research Unit, Social Research Institute, Chulalongkorn University, Bangkok, Thailand \\ E-mails: ${ }^{1}$ sudawan.so@ssru.ac.th ; ${ }^{2}$ thitinanc@swu.ac.th $;{ }^{3 *}$ kittisak.j@chula.ac.th (Corresponding author)
}

Received 15 July 2019; accepted 10 January; published 30 March

\begin{abstract}
This research study is based on analyzing the variables, which assess the Thailand's paddy production. Similarly, the TFP in Thailand's paddy production can be determined through these factors. Moreover, the substitution elasticity between capital and labor has been measured in this research. Further, the substitution elasticity between the older and young farmers has been tried to be investigated. It is expected that the results of research would offer suitable suggestions for policy makers to improve the level of paddy sub-sector productivity in Thailand. In this study, the first objective is based on analyzing the factors, which assess the paddy production with reference to Thailand. Cobb-Douglas production function has been used in this study. Moreover, the stand error and coefficient of determination have been used to assess the regressors, which are significant. The study has used production function to formulate the problem. The findings of the study have revealed the fact that A crucial role is played by productivity in improving the paddy production of country. Therefore, there is need for determining the level of paddy production to be sufficient (high enough) or insufficient. Productivity can be measured in different ways. The measurement of productivity is based on the type of information of the productivity available.
\end{abstract}

Keywords: agricultural production; production function; Thailand

Reference to this paper should be made as follows: Somjai, S., Chankoson, T., Jermsittiparsert, K. 2020. An economic analysis of agricultural production function on the paddy fields of Thailand. Entrepreneurship and Sustainability Issues, 7(3), 2012-2025. https://doi.org/10.9770/jesi.2020.7.3(38)

JEL Classifications: Q10, Q13

\section{Background}

Apart from being a staple food and a source of calorie, paddy sub-sector is vital in influencing the Thailand political environment. In the Thai political perspective, the government has formulated several policies involving subsidies and incentives, a target of 10-tonne productions per-hectare programme and paddy mini-estate. All of the above policies are tools to achieve multi-racial unity in Thailand, which will be achieved if the government can reduce poverty and income gap between agricultural (paddy farmers) and non-agricultural sectors. Thus, through unity, Thailand can create political stability and a stable government which promotes national development (Jermsittiparsert, Sriyakul, \& Pamornmast, 2012; Jermsittiparsert, Sriyakul, \& Rodoonsong, 2013; Sriyakul \& Jermsittiparsert, 2017) 
In addition, in 2009, this sector also provided employment opportunities to 316,000 Thai farmers (Fahmi, Samah, \& Abdullah, 2013). There were about 116,000 full-time farmers who have made this sector as the main source of income. Meanwhile, there were more than 200,000 paddy farmers that have made this sector as the second source of income (Fahmi et al., 2013; Fatah \& Cramon-Taubadel, 2017). Apart from providing employment opportunities, this sector also becomes a source of income for farmers. However, the total incomes earned by paddy farmers are relatively low, which has contributed to the high rate of rural poverty. In 1980, the rural poverty rate was about 37.4 per cent. Approximately 73 per cent of the rural poverty is contributed by paddy farmers. Most of these farmers have an average monthly income of less than RM1,500 per month (Kamaruddin, Ali, \& Saad, 2013). However, in 2009, the rural poverty rate has decreased to 8.4 per cent. To some extent, this shows that there is an improvement in the rural poverty rate in Thailand. Nevertheless, in 2009, the rural poverty rate ( 8.4 per cent) was still high compared to the urban poverty rate (1.7 per cent). A majority of the poor people in rural areas are associated to the paddy farming (Fahmi et al., 2013). For THAILAND, the total poverty rate was recorded about 1.4 per cent out of the amount, which is 1 per cent under hard-core poor. If we assume that the poverty rate for all granary and nongranary areas 4 equals to 1.4 per cent, therefore, the total poverty rate in paddy sub-sector exceeds 11 per cent. Overall in Thailand the paddy production (Figure 1).

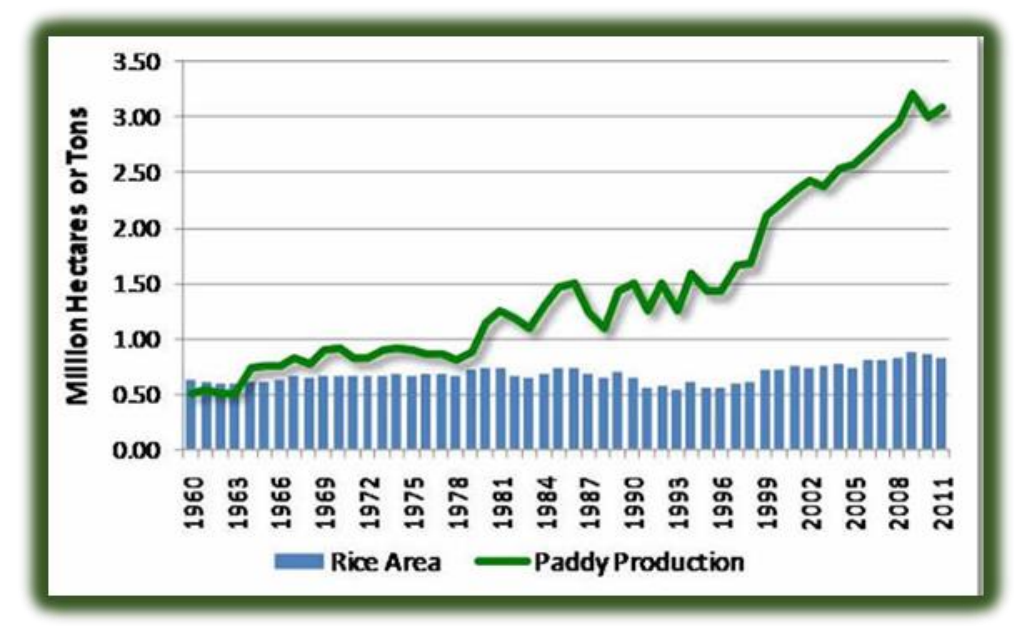

Figure 1. Paddy production in Thailand Source: USDA

As mentioned by Zhou and Liu (2019) and Ligon and Sadoulet (2018), poverty has a positive relationship with a total production. Therefore, it is assumed that 11 per cent poverty will cause a large fall in production. Even globally the paddy production during current decade has increased significantly (Figure 2).

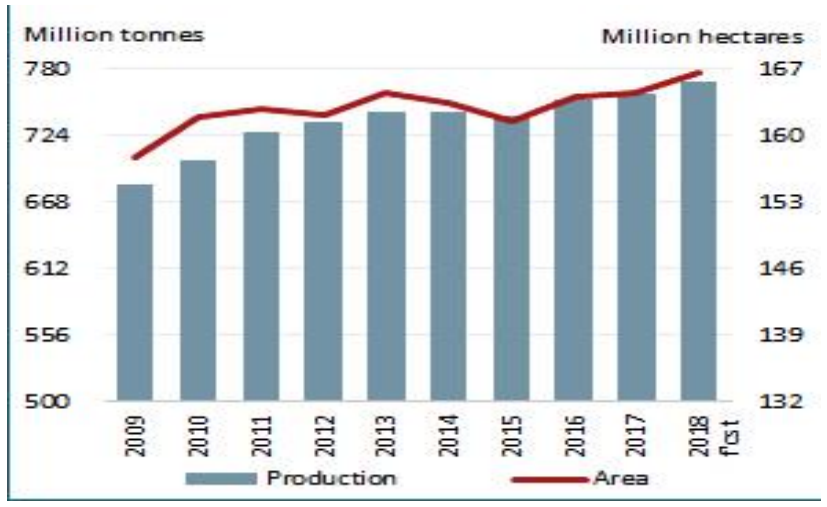

Figure 2. Global paddy production and area

Source: Food and agriculture association of United Nations 
ENTREPRENEURSHIP AND SUSTAINABILITY ISSUES

ISSN 2345-0282 (online) http://jssidoi.org/jesi/

2020 Volume 7 Number 3 (March)

http://doi.org/10.9770/jesi.2020.7.3(38)

Among the identified factors that contribute to the high poverty rate is the age factor. On the average, the farmers' age that is involved in paddy farming is more than 60 years. At this age, farmers are no longer effective to execute any physical works in paddy fields. This has contributed to the low level of productivity in the paddy subsector. Another factor that has contributed to higher poverty rate is the low level of education among paddy farmers. Low education levels contributed to paddy farmers with the problems in obtaining lucrative income from the farming activities (Moyo, Francis, \& Bessong, 2018). Several studies have shown that the economic situation has a direct relationship with a poverty rate Zhou and Liu (2019). This is because the economic growth will reduce poverty rates whereas the economic slowdown will lead to the increase of farmers' poverty rates. This is true for the Thailand case in which we cannot reduce poverty rates especially those of farmers' poverty when they were paired with economic slowdown in 1997. Various policies and programmes have been carried out by the government to ensure farmers get high returns from paddy-farming activities. These directly affect the farmers' income level and, perhaps, could drive them out of continuous poverty. However, the government has also needed to ensure that the prices paid by rice consumers are at the affordable level (Sinha \& Sheth, 2018). Basically, all the government's paddy-and-rice policies are to make sure that Self Sufficiency Level (SSL) for rice increases and are enough to meet the local rice demand. Additionally, the important objective in every policy and programme is to increase farmers' productivity. This is because when farmers' productivity increases, their income would also increase. This will enable the country to achieve rice self-sufficiency rate (Sinha \& Sheth, 2018).

The productivity has to be increased by the farmers for increasing the production of paddy. A crucial role is played by the improvement in level of productivity in increasing the paddy production of a country (Jones, 2018). For increasing the paddy production in an effective manner, there is need for exploring the variables, which significantly affect the level of production. The efficiency of every input can be measured through the information of production input. After the determination of the significant input of production of paddy, the TFP (total factor productivity) can proceed. Technological and labor progress is linked with the TFP (total factor productivity). It is crucial to determine the substation elasticity between the technological progress and labor input. The production can be determined as labor or capital intensive with the estimate of substitution elasticity in the paddy production. Moreover, different farmers' age can be included in paddy production. It is critical to assess the substitution elasticity between the old and young farmers. The farmer's productivity increases as per this finding. The TFP sub sector of paddy is indirectly increased with the increase in farmers' productivity.

By using the approach of production function, the TFP can be measured systematically (Jones, 2018). This research study is based on analyzing the variables, which assess the Thailand's paddy production. Similarly, the TFP in Thailand's paddy production can be determined through these factors. Moreover, the substitution elasticity between capital and labor has been measured in this research. Further, the substitution elasticity between the older and young farmers has been tried to be investigated. It is expected that the results of research would offer suitable suggestions for policy makers to improve the level of paddy sub-sector productivity in Thailand. In this study, the first objective is based on analyzing the factors, which assess the paddy production with reference to Thailand. Cobb-Douglas production function has been used in this study. Moreover, the stand error and coefficient of determination have been used to assess the regressors, which are significant.

The second objective in this research is to analyze the growth of TFP in paddy sub sector of Thailand. Cobb-Douglas production function is the common function employed for the determination of TFP. The TFP value can be calculated as the residual between the values added and growth as per the given data on capital and labor input and shared values. The third objective of the study is to measure the substitution elasticity between capital and labor, old and young farmers in the production of paddy. There are several implications of determining the substation elasticity in the production of paddy. It can be used relative to the capital and labor employed in the process of production. The fourth objective of the study is to analyze the substitution elasticity between the old and young farmers in the production of paddy.

The farmers and policy makers can find this study useful. The study creates and influence in the form of micro as well as macro planning by the top management. The inter-government agencies are involved in the macro planning and the policies are formulated by the policy makers. At the same time, the farmers' mobilization at the level of production is involved in the micro planning. These policies should be implemented by the government in specific actions taken at the level of farm. The actual production takes place at the level of farm. An indirect influence can be obtained by the farmers through different policies, which can be introduced by the government. 
ENTREPRENEURSHIP AND SUSTAINABILITY ISSUES

ISSN 2345-0282 (online) http://jssidoi.org/jesi/

2020 Volume 7 Number 3 (March)

http://doi.org/10.9770/jesi.2020.7.3(38)

\section{Literature review}

The sector of agriculture is an ancient sector of economy all over the world. It has great significance for the social, economic, and political development in almost every country. The history of developments in agriculture has given some unique experience to every developing country. This is distinct for every emerging country, but every country has similar characteristics for the development of agriculture. The share of agriculture sector in majority of the countries is declining. In this way, the contribution of agriculture sector declines in the economic growth and this makes it the third engine. However, its contributions are still significant in the economic development.

The agriculture sector in the emerging economics is not performing optimally. Most of the farmers are working at a small scale, which make their contributions limited. The activities of agriculture are carried out in the form of subsistence and traditional. For this, the investments on agriculture give low returns. Moreover, the family size of the farmers is mostly large, and their income is below the line of poverty. They are not able to support their family in terms of finance. This makes them live in a miserable condition. They are influenced to live in the hard-core poverty. Some researchers have signified these circumstances (Caiazza et al., 2016; Thompson, 2018). These researchers have claimed that same characteristics are shared by the small-scale farmers in the emerging economies including less productivity, inefficiency, and poverty. Usually, the yield is obtained for consumption of family. The surplus is sold. In this way, income earned by the farmers becomes low and this creates an influence in their savings. Resultantly, difficulties are faced by the small-scale farmers in investing and purchasing the quality seeds, machines, and fertilizers. Because of these reasons, the small-scale farmers are facing debt situation in the emerging economies (Ligon \& Sadoulet, 2018). For the strategy formulation to increase the income level of small-scale farmers, several empirical studies have been carried out. It has been suggested by researchers that there is need for improving the quality of life of small-scale farmers particularly in the emerging economies. In order to resolve this issue, it has been suggested to commercialize and re-structure human capital in the sector to make agriculture system systematic.

The training centers of agriculture should be facilitated with modern equipment and laboratories. In this way, skilled human capital can be produced for agriculture sector. The grade, production, and quality of products in the agriculture sector can be improved. The prices of the products will be competitive as well. The efforts are not precise and certain challenges exist in the way. The local communities may resist the change. Several people consider the agriculture field as a third-class job and are not involved in it. Among these people, most are the young people. Because of this perception, unemployment has increased in the rural areas. Moreover, there are several job opportunities in the urban region, which influence young people to migrate there for the sake of employment. The job opportunities in the cities are filled by the young's influx. The unemployment rate among the youngsters is tried to be reduced by these circumstances. The rate of unemployment in the urban region is not more than 10 percent yearly (Giannakis \& Bruggeman, 2015; Wharton, 2017).

The economies of dualism are still being practiced by the developing countries. It shows that both the modern and traditional sectors exist altogether and have some major contributions in the growth of economy. There is more capital employed in the industrial sector and skilled labor is required. There are several unskilled people in the agriculture sector, and they are dependent on the traditional techniques of agriculture. The modern techniques are employed by the farmers who work at large scale. Therefore, they enjoy greater returns as well.

\subsection{Agricultural and Economic Development}

In the essay "An Inquiry into the Nature and Causes of the Wealth Nations", Adam Smith detailed the causes and determining factors of economic growth. He presumed that the level of market size limits the labor division, which helps in understanding the concept of wealth creation. Entrepreneurship is influenced to innovate because of the market size development. The specialized labor is created through major capital investments. Adam Smith claims that this can increase the labor productivity. The capital accumulation, economic development, and savings can be increased (Lucas \& Fuller, 2017).

The problems of economic development have also been discussed by the classical economists such as Staurt Mill, Ricardo, and Malthus. For instance, in the famous book The Principles of Political Economy and Taxation", Ricardo claimed that the most dominant sector of a country is agriculture sector. The book was published in 1971. The people were classified as 
investors, capitalists, and labors. It was also stated that land is a scare factor and competition exists over its utilization (Lucas \& Fuller, 2017). The land comes under competition for being used in agriculture or industry. Ricardo in his book said that there come changes in technology with the passage of time. The economic growth can occur rapidly because of the changing in the technological level. Moreover, the stationary state can be avoided by the technological changes. Therefore, the economic development can be enhanced by the changes in technology. It was added by Ricardo that agricultural development is based on labor. The wage rate paid to the labor determines their continuity for working in the agricultural sector. The minimum level of wage determines the increase or decrease in the labor force. When the owners receive rate of return, which is higher than the minimum benefit received, this results in accumulation. In this way, investors are attracted to invest their money for getting higher returns. There can be decline in the marginal product with the increase in employment in a limited area of land. To resolve this issue, it has been suggested by Ricardo that technology can be used and capital should be accumulated. The productivity of labor increased with this accumulation. Marx also argued the concept of capital accumulation for economic growth. This was later discussed by Domar, Kaldor, and Harrod, being the members of neo Keynesian and neo classical economics. It was thought by neo-Keynesian and neo-classical economics that the agricultural productivity can be increased by savings.

Therefore, it must be ensured that investment should be made in the industrial and agriculture sector. It has been suggested by Schumpeter that some internal agents promote the development that can result in a new set of factors of production. These were named as entrepreneurs by Schumpeter. Similarly, the process of development happens when the ideas of employers are supported with the talent of entrepreneurs. The development process is supported by different factors and infrastructures such as finances and physical provisions.

There is a key role of agriculture sector in the economy particularly in the initial development stages as per the perspective of economic development (Awokuse \& Xie, 2015; Inam \& Effiong, 2017; Vigliarolo, 2020).

A large surplus is produced by the agriculture sector that is necessary for economic transformation. Alternatively, this role is not performance by the non-agriculture sector because of their small size. Therefore, these limitations should be overcome by the agriculture sector in the emerging economies. The non-agriculture sectors cannot progress until these challenges and obstacles are overcome.

Higher wages for the employees can be the result of improvements in the non-agriculture sectors. This makes them able to spend more on necessities such as food and clothing. Resultantly, the demand for food can increase. The food supply is inelastic that reflects that it cannot change with the change in price. When the demand increases for food, this can shift the prices of food products. A negative influence is incurred on the society with the increase in the food prices. This problem can be solved through imports. This can be an expensive solution due to financial constraints. The economic transformation can be encouraged by the changes in the agriculture sector (Sender, 2016). A crucial role is played by agriculture sector in the initial stages of transformation of economy. This occurs in various ways. The income and resident's welfare may increase because of growth in the agriculture sector in the respective economies. This makes them able to raise demand for the food products and other services developed by the non-agricultural sectors (Rehman, Chandio, \& Jingdong, 2017).

The development of industry based on agro is encouraged with the improvements in the agriculture sector. The growth of agro-based industry is dependent on the downstream sectors such as textiles, fuel, beverages, food, and machines. The industry based on agro is crucial as it can offer input of production for industries including pesticides, agricultural machinery, and fertilizers (Wiggins, Sabates-Wheeler, \& Yaro, 2018). Infrastructure increased with the development of agro based industry in the rural and urban regions, which is supported by the government.

\subsection{Developments in Production Function Analysis}

Production function is an important economic analysis tool which has evolved over time. There are two school of thoughts regarding the production function's pioneers, where one views Philip Wicksteed as the pioneer of production function while other states Johann von Thunen as the first pioneer. Production concept refers to skillfully arranging the acquired knowledge and does not act as a tool for representing consequences of the economic choices. Rather, it acts as a tool for obtaining an entity which could affect the economic decision-making. 
ENTREPRENEURSHIP AND SUSTAINABILITY ISSUES

ISSN 2345-0282 (online) http://jssidoi.org/jesi/

2020 Volume 7 Number 3 (March)

http://doi.org/10.9770/jesi.2020.7.3(38)

Economic efficiency is the main area of concern which often get highlighted while analyzing the production function. The researchers (Chukwuji, Inoni, \& Oyaide, 2006; Leibenstein, 1966) suggested that economic efficiency is of two types, namely; resource allocative efficiencies and technical efficiencies. The term efficiency relates to the knowledge engineering. Although several empirical researchers assume that production functions do not involve any managerial, technical and engineering efficiencies. Assuming this, several previous researches (Chukwuji et al., 2006) have particularly focused upon the allocative efficiency of resources which presents an ideal combination of resource and technical allocation efficiencies.

Generally, a physical relation exists among input and output, such as one machine and one labor combination will produce many output units. The literature frequently uses financial values for indicating input-output relationship. A few studies have also shown the use of different physical units for measuring the input-output relationship. It may cause certain problems while performing the empirical analysis, involving undivided units. However, there is another opinion by Faber, Proops, and Baumgärtner (1998), that production process means producing various number of outputs. Therefore, a weighted price can be observed to consider the difference in products. Thus, the wastage and error involved in the physical production process can be isolated.

It has often been assumed by researchers that the technical efficiency issues of a firm can be resolved through the production function, but in fact it is a false proposition because for each variable different measuring unit is used. Apart from this, production function must not be taken as a business model, since it ignores several cost and management aspects. Thus, to avoid such problems, a non-parametric approach i.e. Data Envelopment Analysis (DEA) was suggested by several researchers (Angelidis \& Lyroudi, 2006; Banker, Charnes, \& Cooper, 1984). According to Emrouznejad and Thanassoulis (2001), the DEA approach can measure multiple input-output analyses and does not involve mathematical forms in its production function.

Knut Wicksell is the pioneer of developing algebraic hypothesis into physical agricultural production functions, in agricultural economics field. He reported positive increasing returns on labor and capital when applied to infertile soil. Based on this hypothesis, he explained that the quality and quantity of inputs determine the size and growth of agricultural output. In Knut Wicksell's view, the input-output relationship can be demonstrated in mathematical form. Thus, for a certain period of time, if $\mathrm{X} 2, \mathrm{X} 2$, and $\mathrm{X} 3$ are the inputs and $\mathrm{P}$ denotes the total output, then production function can be presented as follows: $\mathrm{PR}_{\mathrm{t}}=\mathrm{f}\left(\mathrm{X}_{1}, \mathrm{X}_{2}, \mathrm{X}_{3}\right)$.

Tough, Wicksell was the key person who has formulated a basic production function, the first empirical estimation which was performed by Cobb and Douglas (1928). The production function was later known as Cobb-Douglas Production Functions (CD). The origin of certain functions can be traced back to the work of Wicksell.

$\mathrm{PR}_{\mathrm{t}}=\mathrm{f}\left(\mathrm{X}_{1}^{\alpha}, \mathrm{X}_{2}^{\beta}, \mathrm{X}_{3}^{\gamma}\right)$.

According to Wicksell, the coefficient for Equation 2 above can be unity and have a constant return to scale. In Charles W. Cobb's and Paul H. Douglas's study, a similar production function was used by them as proposed by Wicksell. They used the data on the U.S. manufacturing industries from 1899- 1922. Cobb's and Douglas's work was the first empirical work using time-series data. Generally, the form of production function is as follows:

$\mathrm{PR}_{\mathrm{t}}=\mathrm{bL}^{\mathrm{k}} \mathrm{C}^{1-\mathrm{k}}$

where $\mathrm{P}$ is output, $\mathrm{L}$ is labour and $\mathrm{C}$ is capital input in the industry. The estimation was resulted from the production function model which used by Charles W. Cobb and Paul H. Douglas, as follows:

$\mathrm{PR}_{\mathrm{t}}=1.0 \mathrm{~L}^{0.75} \mathrm{C}^{0.25} \ldots \ldots . .$. (4)

From Equation 4 above, Cobb and Douglas (1928) have indicated that a combination among labour and capital coefficients equals to one. They also indicated constant returns to scale. This finding has confirmed the Wicksell's earlier hypothesis. If the coefficient is greater or lesser than one, then the total product may be larger or smaller than the number of combinations of input used. Therefore, we can identify whether the firms enjoy anincreasing or decreasing marginal productivity. In another study, Cobb and Douglas (1928) have stressed on the unitary degree of elasticity or the amount of elasticity of resources which are equivalent to one. They have employed the function, $\mathrm{PR}_{\mathrm{t}}=\mathrm{bL}^{\mathrm{k}} \mathrm{C}^{1-\mathrm{k}}$ where the coefficient $\mathrm{j}$ and $\mathrm{k}$ can take a non-zero value. The Cobb-Douglas's production function has become popular until today. This is because the CobbDouglas's production functions are the simplest production function. After the development of a production function that was highlighted by Cobb and Douglas (1928), the study of the production function became popular among numerous researchers (Fraser, 2002). There are various forms of estimation which can be carried out by using the production functions. The study of production function can be broken down into several types of data, such as the cross-sectional, time series, and panel data. 
ENTREPRENEURSHIP AND SUSTAINABILITY ISSUES

ISSN 2345-0282 (online) http://jssidoi.org/jesi/

2020 Volume 7 Number 3 (March)

http://doi.org/10.9770/jesi.2020.7.3(38)

In addition, there are also some other alternatives of the production function which is essentially used in empirical estimation. Among them are Constant Elasticity of Substitution (CES), Variable Elasticity of Substitution (VES), and translog and other flexible production functions (Christensen, Jorgenson, \& Lau, 1973; Lu \& Fletcher, 1968).

\subsection{Single Output Production Functions}

The production function knowledge has grown enormously since 1970s. During this period, the development of the knowledge has brought a number of prominent scholars. Among them were Turgot, Johann von Thunen, Philip Wicksteed, Malthus, Cobb and Douglas (Hussain et al., 2019). Since then, the production-function development has been a crucial tool in empirical analysis in all economic schools of doctrine. Returning to the historical development of the production functions, many scholars believed that Turgot was the first scholar to have introduced the production functions knowledge around 1767. According to Schumpeter (1954), Turgot has argued how the dissimilarity in factor proportions affects the marginal productivity of production. Based upon Turgot's observations, the utility of consumption of one product may reduce if the supply of the product increases. The increase in quantity of production input may increase the productivity up to a maximum point. After this point, the increasing in the unit of input used may decrease the marginal productivity level to zero. Eventually, if there are more input units added, the productivity may turn to negative. Consequently, after a maximum point, additional input may be unproductive. Subsequently, more than thirty years after Turgot, the production functions knowledge has evolved. Several scholars have successfully connected to this development such as Johann von Thunen and Philip Wicksteed (Mishra, 2007). The numerical concept of the production functions has been introduced by Malthus. Towards this, Malthus introduced the logarithmic production function in 1978. The idea of logarithmic production functions is to capture the law of diminishing returns. To facilitate the description of his model, Malthus specified that the population increases by the geometric ratio $(1,2,4,8,16,32 \ldots)$ while land increases the arithmetic ratio $(1,2,3,4,5 \ldots)$. Malthus has then presumed that labour may experience diminishing returns when combined with land.

Following Malthus, David Ricardo introduced the idea of a quadratic production function in 1817. According to Ricardo, the growth may stop when diminishing return of capital is combined with limited land. At this point, the investment may drop. This is because the economic growth may have reached the stationary phase. After Malthus and Ricardo, Johann von Thunen has introduced the exponential production function. In fact, he was the first person to have used this function. Von Thunen exponential production function can be written as follows (Mishra, 2007):

$\mathrm{PR}_{\mathrm{t}}=\mathrm{f}(\mathrm{G})=A \Pi_{1}^{3} 1.0-\mathrm{e}^{-\mathrm{a}_{\mathrm{i}}, \mathrm{G}_{\mathrm{i}}} \ldots \ldots \ldots$ (5)

where G1, G2, and G3 are the labour, capital, and fertiliser, ai is a parameter. PR is the von Thunen's production function (Blaug, 1985; Lloyd, 1969). According to Lloyd (1969), von Thunen was probably the first economist to have applied the theory of differential calculus in calculating the level of productivity. Lloyd has also believed that von Thunen was perhaps the first person to use calculus to solve the problems of economic optimisation. He further added that von Thunen also has used calculus to interpret the marginal productivity of economic production function. He was the first to formulate that algebraic production functions as Equation 6

$\mathrm{WPR}_{\mathrm{t}}=$ eff $* \mathrm{CPW}^{\mathrm{n}}$.

$W_{P R} R_{\mathrm{t}}$ is the output per worker WPR, capital per worker is CPW. Thunen's production function with L (labour) such as:

$\mathrm{L} * \mathrm{WPR}_{\mathrm{t}}=\operatorname{eff} * \mathrm{CPW}^{\mathrm{n}} * \mathrm{~L} \ldots \ldots \ldots \ldots$ (7)

Based on the above equations, we can conclude that the von Thunen's production function is a hidden Cobb-Douglas's production function (Blaug, 1985; Lloyd, 1969). Based on Equation 7, von Thunen has discovered that labour alone cannot be an effective production input. Von Thunen has then transformed Equation 7 to be Equation 8 (Mishra, 2007).

$\mathrm{WPR}_{\mathrm{t}}=\operatorname{eff} *(\mathrm{~L}+\mathrm{CPW})^{\mathrm{n}} \cdot \mathrm{L}^{\mathrm{n}-1} \ldots$

Nevertheless, after a long review process, von Thunen corrected his early notation about labour. In his new discovery, he has found that labour alone can produce product. However, modern economists have never formulated a production function by using labour as the sole factor of production. In addition, in 1923, another scholar named Wicksell introduced a production function that is similar to CobbDouglas's production function with an exponential of up to unity. Based on the previous work, Samuelson (1979) presumed a Cobb-Douglas's production function as merely a special case for other production functions. The CoobDouglas's production function can be written as follows:

$\mathrm{PR}_{\mathrm{t}}=\mathrm{AL}_{\mathrm{i}}^{\beta_{1}} * \mathrm{CAP}_{\mathrm{i}}^{\beta_{\mathrm{n}}} * \mathrm{e}^{\mu} \ldots . . . .$.

where $i=1,2,3 \ldots \ldots n$ 
where, PR is output, $\mathrm{L}$ is labour, CAP is capital, $\mu$ is a stochastic disturbance term. $\beta_{1}$ and $\beta_{2}$ are the elasticises of output with respect to the input of production respectively. Meanwhile, the Marginal Rate Technical of Substitution (MROTS) can be written as follows: -

MROTS $=\frac{\text { MP }_{\text {LAP }}}{\text { MP }_{\mathrm{L}}} \ldots(10)$

Equation 11 and 12 define the total cost (COST) and the isocost line, respectively, in terms of the quantity of labor (L), the quantity of capital (CAP), the wage rate (w), and the rental price of capital (r).

$\operatorname{cosT}=w \mathrm{~L}+\mathrm{rCAP}$

$$
\mathrm{CAP}=\frac{\operatorname{COST}}{\mathrm{r}}-\frac{\mathrm{W}}{\mathrm{r}} \mathrm{L} \ldots \ldots \ldots(12)
$$

Equations 13 and 14 are the alternative ways of expressing the necessary condition for the optimal combination of inputs. The first states that the optimum combination is found where the absolute value of the slope of an isoquant (MROTS) is equal to the absolute value of the slope of the isocost line. The second notes that the marginal rate of technical substitution is equal to the ratio of the marginal products of labor and capital and is therefore equal to the absolute value of the slope of the isocost line at the optimum. The last rewrites the second to show that it implies that the optimum combination of inputs is found where the marginal product of an input divided its cost per unit is the same for all inputs.

$$
\begin{aligned}
& \frac{\mathrm{MP}_{\mathrm{ENP}}}{\mathrm{MP}_{\mathrm{L}}}=\frac{\mathrm{w}}{\mathrm{r}} \ldots \ldots \ldots(13) \\
& \text { MROTS }=\frac{\mathrm{MP}_{\mathrm{ENP}}}{\mathrm{MP}_{\mathrm{L}}}=\frac{\mathrm{w}}{\mathrm{r}} \ldots \ldots \ldots . .
\end{aligned}
$$

The elasticity of substitution of the Cobb Douglas's production function can be expressed as follows:

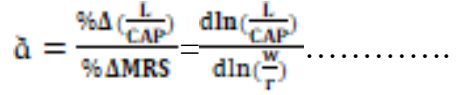

If $\mathrm{a}=1$, means that any changes in $\mathrm{L} / \mathrm{K}$ will be matched by a proportional change in wlr and the relative income that is earned by capital and labour will stay constant. After 33 years, Cobb-Douglas's production function was introduced. Arrow, Chenery, Minhas, and Solow (1961) made some modifications to the function. However, the changes were only an extension of the Cobb Douglas's production function, not an alternative paradigm. One of the Cobb-Douglas's production function properties is that the elasticity of substitution between capital and labour is constrained to unity. However, the production function that was formulated by Arrow et al. (1961) allows the elasticity of substitution labour and capital to be flexible and the value lies between zero and infinity. This function is known as a Constant Elasticity of Substitution (CES). The CES value lies between the CobbDouglas's, Leontief's, and linear production functions. Therefore, we said that the CES production function is a special case for those three production functions above. Nevertheless, its value remains fixed along and across isoquant and ignores the size of output or input into the production process. The CES function can be written as follows:

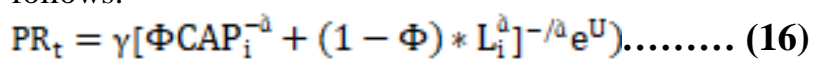

where $\mathrm{PR}_{\mathrm{t}}$ is value-added, CAPi is capital, and Li represents labour. Notations $\gamma, \Phi$ and $\tilde{a}$ are the efficiency, distribution, and substitution parameters. Meanwhile, the random errors are UI, U2 and Un. Basically, we assume that the random errors are independent and normally distributed. The number of samples was represented by $\mathrm{n}$. Under the perfect competition, the elasticity of substitution for CES production function is $=(1+p)^{-1}$. Transformed Equation 9 to $\log$ functions as follows:

$\log \left(\frac{P R_{i}}{L_{\mathrm{i}}}\right)=\theta_{0}+\theta_{1} \log w_{\mathrm{i}}+U_{\mathrm{i}}$,

where $i=1,2,3 \ldots \ldots$...

$w_{\mathrm{i}}$ is wage for labour while $\theta_{1}$ is the CES elasticity of substitution. If the CES elasticity substitution value is $1(\mathrm{a}=\mathrm{I})$, then we have a Leontief production function. If the elasticity substitution of CES approaches zero, then we get the linear homogeneous Cobb-Douglas's function. Meanwhile, if $\mathbf{o}$ approaches negative infinity, then we get the Leontief s function. Conversely, there are two problems that are related to the CES production function. The first problem is the elasticity of substitution that is constant along and across the isoquant. The second problem is that the researcher used more than two inputs. For example, if there are three inputs of CES production function that may yield three values of elasticity. However, according to the impossibility theorems of Uzawa and McFadden, it is impossible to get the value elasticity if the number of inputs used is more than two (Mishra, 2007). The next production function is the Variable Elasticity of Substitution (VES). 
Scholars such as (Hildebrand, Liu, \& Liu, 1965) and Lu and Fletcher (1968) generalised the CES production function to allow the Variable Elasticity of Substitution (VES). The VES production function can be written as follows:

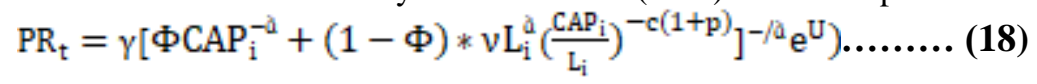

The random error $(\mathrm{U})$ is independent and normally distributed. Equation 18 is then transformed to log as follow: -

$\log \left(\frac{\mathrm{PR}_{\mathrm{i}}}{\mathrm{L}_{\mathrm{i}}}\right)=\theta_{0}+\theta_{1} \log w_{\mathrm{i}}+\theta_{2} \log \left(\frac{\mathrm{CAP}_{\mathrm{i}}}{\mathrm{L}_{\mathrm{i}}}\right)+\mathrm{U}_{\mathrm{i}} \ldots$

where $\theta_{0}, \theta_{1}$ and $\theta_{2}$ are the coefficient of the logarithm of capital-labour ratio. If the value is zero, then the model is reduced to Constant Returns to Scale (CES) production function as Equation 14 The elasticity of substitution for the VES production function can be expressed as follows:

$\tilde{\mathrm{a}}=\theta_{1}\left(1-\varepsilon \theta_{a}\right)^{-1)} \ldots(20)$

where $\varepsilon$ is the ratio of total factor costs to the rental cost of capital? In mid-1970s, the generalized Cobb-Douglas's production function and the CES were almost complete. Both of these functions assume that the marginal rate technical of substitution (MRTS) of factors of production is contributed by changes in a factor price. In addition, both Cobb-Douglas's and CES production functions are free from the technical progress. These mean that any technological progress may not affect the labor and capital change in the production function. In technical terms, this situation is called Hicks-neutral.

Basically, there are three types of neutrality; Hicks, Harrod, and Solow. Nonetheless, changes in technology may cause changes in production possibilities. Hicks-neutral situation is related to changing in technology. However, the changes in technology may not affect the capital-labor ratio if a factor price is unchanged. Meanwhile, a technological change is assumed to be Harrod-neutral if the changes in technology do not affect a capital-labor ratio when capital price is unchanged. In the meantime, the technological change is Solow-neutral if the labor is unchanged. The unchanged labor may cause a capital-labor ratio to be unchanged.

\section{Method}

There are several methods that are available to test the long-run relationship between regresor such as residual model by Granger (1987), and Johansen and Juselius (1990). However, the present study employed the autoregressive distributed lag (ARDL) approach developed by Pesaran, Shin, and Smith (2001). This technique has been popular for recent years and is often used to analyse the long-run relationship between the regressor in the empirical model. This technique also allows the dynamic interactions among the variables. There are a few reasons why this technique is chosen. First, ARDL model gives power and testing of the long-run relationship for the different order of integration, while the other method required all the explanatory integrated in the same order. Therefore, ARDL method is not required for pre-testing of the order of integration of the variables in the model. Hence, ARDL approach to cointegration can be applied regardless of whether the underlying explanatory variables are purely I(O), purely I(1) or mutually co-integrated (Verma, 2007). However, for the accurate result, the response variable needs to be integrated at order one I(1). According to Pesaran et al. (2001), when pre-testing is involved, a certain degree of uncertainty $(\mathrm{I}(\mathrm{O}), 1(1)$ or mutually cointegrated with regard to the analysis of level relationships is created. Therefore, this situation may create problems to the researcher in selecting the appropriate method of analysis. Furthermore, numerous scholars claim that unit root tests lack power and have poor size property especially in small sample size series (Virmani, 2004).

$$
\begin{aligned}
& \ln \mathrm{PR}_{\mathrm{t}}=\frac{a_{0}}{\mu \mathfrak{d} \mathrm{d}}+a_{1} \ln P a d A_{\mathrm{t}}+a_{2} \operatorname{lnlabB30_{\mathrm {t}}}+a_{\mathrm{a}} \operatorname{lnlaA60_{\mathrm {t}}}+a_{4} \ln \operatorname{Cap}_{\mathrm{t}}+a_{5} \ln A v g P P_{\mathrm{t}}+a_{6} \ln A v g F U_{\mathrm{t}}+
\end{aligned}
$$

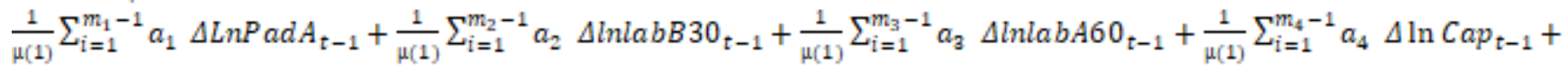

$$
\begin{aligned}
& \frac{1}{\mu(1)} \sum_{i=1}^{m_{5}-1} a_{5} \Delta \operatorname{lnAvg} P P_{t-1}+\frac{1}{\mu[1\}} \sum_{i=1}^{m_{5}-1} a_{5} \operatorname{lnAvg} F U_{t-1} \\
& +\varepsilon_{\mathrm{t}} \ldots \text { (21) }
\end{aligned}
$$

Where,

In $\mathrm{PR}_{\mathrm{t}^{\mathrm{s}}}$ natural logarithm of average paddy yield for main and off season in metric ton per hectare

LnPadA: Area cultivation (hectare) per season.

lnlabB30:labour age below 30 to 60 years old ('000) per season 
lnlabA60: labour age below 61to 71 years old ('000) per season

In Cap: cost of capital used (Bahts) per hectare.

lnAvgPP: Natural logarithm average local paddy price

$\ln A v g F U$ : Average fertilizer used.

\section{Results}

\section{Results and Disccussions}

The results of the correlation test between dependent variable and independent variables proved to be very useful in pre estimation analysis especially as regards potential relationships suggested by theories. Therefore prior to the econometrics analysis, the statistical correlation of the variables are examined which helped in determining the statistical relationships between and amongst the variables (see Table 1).

Table 1. Correlation Analysis

\begin{tabular}{clllllll}
\hline & PR & PadA & labB30 & labA60 & Cap & AvgPP & AvgFU \\
\hline PR & 1.00 & & & & & & \\
PadA & -- & & & & & & \\
& 0.15 & 1.00 & & & & & \\
labB30 & $(0.41)$ & -- & & & & & \\
& 0.20 & 0.13 & 1.00 & & & & \\
labA60 & $(0.27)$ & $(0.48)$ & -- & & & & \\
& 0.26 & -0.13 & 0.41 & 1.00 & & & \\
Cap & $(0.15)$ & $(0.46)$ & $(0.02)$ & -- & & & \\
& 0.03 & -0.12 & 0.43 & 0.03 & 1.00 & & \\
AvgPP & $(0.87)$ & $(0.52)$ & $(0.01)$ & $(0.88)$ & -- & & -00 \\
& $(0.71)$ & 0.42 & 0.51 & 0.29 & 0.72 & 1.00 & \\
AvgFU & 0.43 & $0.59)$ & $(0.21)$ & $(0.48)$ & $(0.38)$ & - & \\
& $(0.51)$ & $(0.57)$ & $(0.32)$ & $(0.20)$ & $(0.34)$ & $(0.32)$ & -- \\
\hline
\end{tabular}

ASEAN's optimum models selection was undertaken as depicted by Table 2 and the Table 3 . The selected models are , ARDL $(1,1,0,2,1,0,1,2,0,0,0,0)$ 
ENTREPRENEURSHIP AND SUSTAINABILITY ISSUES

ISSN 2345-0282 (online) http://jssidoi.org/jesi/

2020 Volume 7 Number 3 (March)

http://doi.org/10.9770/jesi.2020.7.3(38)

Table 2. ARDL IV Long-run Estimates

\begin{tabular}{|c|c|c|c|c|}
\hline \multirow[t]{2}{*}{ Variables } & Coefficien & Standard & \multirow{2}{*}{$\begin{array}{c}t- \\
\text { statistics }\end{array}$} & \multirow[t]{2}{*}{$p$-Value } \\
\hline & ts & Error & & \\
\hline \multicolumn{5}{|c|}{ ARDL $(1,1,0,2,1,0,1,2,0,0,0,0)$} \\
\hline $\operatorname{lnPad} A$ & 0.415 & 0.142 & 1.522 & 0.238 \\
\hline $\operatorname{lnPadA}(-1)$ & 0.455 & 0.147 & 3.090 & $0.006 * * *$ \\
\hline InlabB30 & 0.010 & 0.019 & 1.427 & 0.224 \\
\hline $\operatorname{lnlabB30}(-1)$ & 0.000 & 0.201 & 5.938 & $0.000 * * *$ \\
\hline InlabA60 & -0.477 & -0.137 & -3.498 & $0.232 *$ \\
\hline $\operatorname{lnCap}$ & 0.001 & 0.001 & 4.202 & $0.003 * * *$ \\
\hline $\ln A v g P P$ & 0.023 & 0.043 & 0.526 & 0.604 \\
\hline $\ln A v g P P(-1)$ & 0.065 & 0.037 & 3.763 & $0.000 * * *$ \\
\hline $\ln A v g F U$ & 0.142 & 0121 & 4.003 & $0.002 * *$ \\
\hline$\triangle \ln P a d A$ & 0.033 & 0.048 & 0.689 & 0.499 \\
\hline$\triangle \operatorname{InPadA}(-1)$ & 0.097 & 0.053 & 1.831 & $0.083^{* *}$ \\
\hline$\triangle \mathrm{labB30}$ & 0.429 & 0.118 & 3.624 & $0.001 *$ \\
\hline$\triangle \mathrm{labA60}$ & 0.000 & 0.000 & 4.158 & $0.000^{*}$ \\
\hline$\Delta \ln C a p(-1)$ & 0.000 & 0.000 & 1.902 & 0.123 \\
\hline$\Delta \ln C a p(-2)$ & 0.000 & 0.000 & 3.352 & $0.003 * *$ \\
\hline$\triangle \ln$ AvgPP & -1.214 & 0.380 & 3.194 & $0.004 * *$ \\
\hline$\Delta \ln A v g F u$ & -0.291 & 0.076 & 3.854 & $0.001 * *$ \\
\hline $\mathbf{C}$ & 7.406 & 2.882 & 2.570 & $0.018^{*}$ \\
\hline $\mathbf{T}$ & 0.045 & 0.009 & 4.731 & $0.000^{*}$ \\
\hline
\end{tabular}

In present study, it has been observed that old and young farmers, capital, land, paddy price, and fertilizers are the significant paddy production inputs and are capable of influencing the production volume both in the short and the long run. Other than being the determinants of paddy production, these factors also play significant role in the productivity growth of paddy subsectors. The integration of these production factors has shown that Thailand occupies a productivity growth rate of less than $5 \%$, which is un-favorable for the overall paddy sub-sectors' growth. However, in the long run, the lower levels of productivity growth will lead to greater dependency upon the rice import. The constantly obtaining lower paddy production levels may create several issues, such as insufficient food supply for satisfying people demand. Thus, the productivity of paddy must be improved to enhance revenues, using better technology, research and development, high quality seeds, and high capital investments. Furthermore, certain cultivation techniques must be introduced which could help in the rice breed germination such as, System of Rice Intensification (SRI) and transplanting.

Meanwhile, there is inelastic substitution between labor and capital with a value close to 1 . This indicates that substitution between labor and capital is not complicated, which implies the willingness of Thai farmers to integrate new technology in their activities. Integration of technology and machinery into farming activities has gradually replaced the labors part in farming, which is further expected to help this sector to switch towards labor-saving technologies. Thus, this research observed that old and young farmers may act as perfect substitutes, thereby implying that no significant impact can be witnessed on the paddy yield with different farming experience, particularly because most farmers in Thailand use similar types of machinery and technology in farming processes. Furthermore, since labor can now be replaced with machines, therefore it is the reason why old and young farmers do not consider as a major area of concern in terms of paddy cultivation. 
ENTREPRENEURSHIP AND SUSTAINABILITY ISSUES

ISSN 2345-0282 (online) http://jssidoi.org/jesi/

2020 Volume 7 Number 3 (March)

http://doi.org/10.9770/jesi.2020.7.3(38)

\section{Conclusion}

The current research has found that land, capital, young farmers, old farmers, fertiliser, and paddy price are the important inputs in paddy production. All these inputs can influence the volume of production either in the short-run or long-run. Apart from being the determining factors in paddy production, all these factors are also important in the paddy sub-sector productivity growth. By using all of these production factors, the study has found that the level of the productivity growth for all four Thailand regions is lower than 5 per cent. This situation is not favorable to the growth of the paddy sub-sector as a whole. In the long-term, if the productivity growth is low, then this will create a dependency on rice import. Even if the level of paddy production is still low, this situation will create problems of inadequate food supply to meet the demand of the people.

Meanwhile, the substitution between capital and labour is inelastic and the value is near to one. These show that the substitution between capital and labor is not so difficult, which indirectly shows that the farmers in the Thailand areas are willing to accept the inclusion of technology in the farming activities. Gradually, the use of machinery and technology has replaced the role of labours in farming activities. This may help this sector towards the labour-saving technologies. Being concurrent with the above findings, the present study has found that young farmers and old farmers are a perfect substitute. These indicate that the difference in fanning experience does not give a significant impact to the paddy yield. This is because young and old farmers in Thailand regions basically use a homogeneous level of technology or machinery. The question of whether young or old farmers are not a major concern in the paddy cultivation in the Thailand areas is because machines can replace labors in a lot of ways.

\section{References}

Angelidis, D., \& Lyroudi, K. (2006). Efficiency in the Italian banking industry: data envelopment analysis and neural networks. International Research Journal of Finance and Economics, 5(1), 155-165.

Arrow, K. J., Chenery, H. B., Minhas, B. S., \& Solow, R. M. (1961). Capital-labor substitution and economic efficiency. The review of Economics and Statistics, 43(3), 225-250. https://doi.org/10.2307/1927286

Awokuse, T. O., \& Xie, R. (2015). Does agriculture really matter for economic growth in developing countries? Canadian Journal of Agricultural Economics/Revue canadienne d'agroeconomie, 63(1), 77-99. https://doi.org/10.1111/cjag.12038

Banker, R. D., Charnes, A., \& Cooper, W. W. (1984). Some models for estimating technical and scale inefficiencies in data envelopment analysis. Management science, 30(9), 1078-1092. https://doi.org/10.1287/mnsc.30.9.1078

Blaug, M. (1985). Where are we now in the economics of education? Economics of education review, 4(1), 17-28. https://doi.org/10.1016/0272-7757(85)90034-2

Caiazza, R., Volpe, T., Stanton, J. L., Griffith, C. J., Haas, R., Meixner, O., \& Petz, M. (2016). Enabling community-powered coinnovation by connecting rural stakeholders with global knowledge brokers. British Food Journal. https://doi.org/10.1108/BFJ-10-2015$\underline{0398}$

Christensen, L. R., Jorgenson, D. W., \& Lau, L. J. (1973). Transcendental logarithmic production frontiers. The review of Economics and Statistics, 28-45. https://doi.org/10.2307/1927992

Chukwuji, C. O., Inoni, O. E., \& Oyaide, W. J. (2006). A quantitative determination of allocative efficiency in broiler production in Delta State, Nigeria. Agriculturae Conspectus Scientificus, 71(1), 21-26.

Cobb, C. W., \& Douglas, P. H. (1928). American economic association. Source: The American Economic Review, 18(1), $139-165$.

Emrouznejad, A., \& Thanassoulis, E. (2001). An extensive bibliography of data envelopment analysis (DEA)(in three volumes). University of Warwick, Coventry, England.

Faber, M., Proops, J. L., \& Baumgärtner, S. (1998). All production is joint production-a thermodynamic analysis. Sustainability and Firms, Technological Change and the Regulatory Environment, Edward Elgar, Cheltenham.

Fahmi, Z., Samah, B. A., \& Abdullah, H. (2013). Paddy industry and paddy farmers well-being: a success recipe for agriculture industry in Malaysia. Asian Social Science, 9(3), 177. https://doi.org/10.5539/ass.v9n3p177 
ENTREPRENEURSHIP AND SUSTAINABILITY ISSUES

ISSN 2345-0282 (online) http://jssidoi.org/jesi/

2020 Volume 7 Number 3 (March)

http://doi.org/10.9770/jesi.2020.7.3(38)

Fatah, F. A., \& Cramon-Taubadel, S. V. (2017). Profitability and Competitiveness of Rice Farming in Malaysia: A Policy Analysis Matrix. Asian Journal of Agriculture and Development, 14(1362-2017-3060), 31-48. http://dx.doi.org/10.22004/ag.econ.265764

Fraser, H. (2002). Change, challenge, and opportunity in pronunciation and oral communication. Paper presented at the Plenary Address at English Australia Conference, Canberra.

Giannakis, E., \& Bruggeman, A. (2015). The highly variable economic performance of European agriculture. Land Use Policy, 45, 26-35. http://dx.doi.org/10.1016/j.landusepol.2014.12.009

Granger, E. R. (1987). Cointegration and Error Corection: Representation. Estimation and Testing E-conometrica, 55, 25. http://dx.doi.org/10.2307/1913236

Hildebrand, G. H., Liu, T.-C., \& Liu, D. (1965). Manufacturing production functions in the United States, 1957: an interindustry and interstate comparison of productivity (Vol. 15): New York State School of Industrial and Labor Relations, Cornell University.

Hussain, H.I., Grabara, J., Razimi, M.S.A., \& Sharif, S.P. (2019) Sustainability of Leverage Levels in Response to Shocks in Equity Prices: Islamic Finance as a Socially Responsible Investment, Sustainability, 11 (12), 3260. https://doi.org/10.3390/su11123260

Inam, U. S., \& Effiong, E. A. (2017). Fadama Iii Project And Output Performance Of Agricultural Enterprises: An Empirical Evaluation. Archives of Business Research, 5(8). https://doi.org/10.14738/abr.58.3506

Jermsittiparsert, K, Sriyakul, T., \& Pamornmast, C. (2012). The "Populism" Policy and Building/Diminishing Economic "Inequality" and "Unfairness": Empirical Suggestion on Pork-Barrel in Thailand's Rice Trading Business. Public Policy and Administration Research, 2(7), 21-31. https://dx.doi.org/10.2139/ssrn.1994431

Jermsittiparsert, K, Sriyakul, T., \& Rodoonsong, S. (2013). Power(lessness) of the State in the Globalization Era: Empirical Proposals on Determination of Domestic Paddy Price in Thailand. Asian Social Science, 9(17), 218-225. http://dx.doi.org/10.5539/ass.v9n17p209

Johansen, S., \& Juselius, K. (1990). Some structural hypotheses in a multivariate cointegration analysis of the purchasing power parity and the uncovered interest parity for UK.

Jones, O. (2018). SME productivity stakeholders: Getting in the right orbit.

Kamaruddin, R., Ali, J., \& Saad, N. M. (2013). Happiness and its Influencing Factors among Paddy Farmers in Granary Area of MADA. Abstract of Economic, Finance and Management Outlook, 1, 1-38. http://dx.doi.org/10.5829/idosi.wasj.2013.28.efmo.27016

Leibenstein, H. (1966). Allocative efficiency vs." X-efficiency". The American Economic Review, 56(3), 392-415.

Ligon, E., \& Sadoulet, E. (2018). Estimating the relative benefits of agricultural growth on the distribution of expenditures. World Development, 109, 417-428. http://dx.doi.org/10.1016/j.worlddev.2016.12.007

Lloyd, P. (1969). Exactly solvable model of electronic states in a three-dimensional disordered Hamiltonian: non-existence of localized states. Journal of Physics C: Solid State Physics, 2(10), 1717. http://dx.doi.org/10.1088/0022-3719/2/10/303

Lu, Y.-c., \& Fletcher, L. B. (1968). A generalization of the CES production function. The review of Economics and Statistics, 449-452. http://dx.doi.org/10.2307/1926812

Lucas, D. S., \& Fuller, C. S. (2017). Entrepreneurship: Productive, unproductive, and destructive-Relative to what? Journal of Business Venturing Insights, 7, 45-49. https://doi.org/10.1016/j.jbvi.2017.03.001

Mishra, S. (2007). Quality assurance in higher education: An introduction: National Assessment and Accreditation Council, India;.

Moyo, C. S., Francis, J., \& Bessong, P. O. (2018). Impact of a biomedical research project on the human capital development of emerging researchers. South African Journal of Science, 114(3-4), 1-6. https://dx.doi.org/10.17159\%2Fsajs.2018\%2F20170090

Pesaran, M. H., Shin, Y., \& Smith, R. J. (2001). Bounds testing approaches to the analysis of level relationships. Journal of applied econometrics, 16(3), 289-326. https://doi.org/10.1002/jae.616

Rehman, A., Chandio, A. A., \& Jingdong, L. (2017). Fertilizer consumption, water availability and credit distribution: major factors affecting agricultural productivity in Pakistan. Journal of the Saudi Society of Agricultural Sciences. https://doi.org/10.1016/j.jssas.2017.08.002

Samuelson, P. A. (1979). Paul Douglas's measurement of production functions and marginal productivities. Journal of Political Economy, 87(5, Part 1), 923-939. http://dx.doi.org/10.1086/260806 
ENTREPRENEURSHIP AND SUSTAINABILITY ISSUES

ISSN 2345-0282 (online) http://jssidoi.org/jesi/

2020 Volume 7 Number 3 (March)

http://doi.org/10.9770/jesi.2020.7.3(38)

Schumpeter, J. A. (1954). History of Economic Analysis, London. New Ideas from Fascinating People.

Sender, J. (2016). Backward Capitalism in Rural S outh A frica: Prospects for Accelerating Accumulation in the Eastern Cape. Journal of agrarian change, 16(1), 3-31. https://doi.org/10.1111/joac.12105

Sinha, M., \& Sheth, J. (2018). Growing the pie in emerging markets: Marketing strategies for increasing the ratio of non-users to users. Journal of Business Research, 86, 217-224. http://dx.doi.org/10.1016/j.jbusres.2017.05.007

Sriyakul, T. \& Jermsittiparsert, K. (2017). Politicization of Rice Price: Who Gain and Who Lose from the Populist Policies to Intervene Rice Price in Thailand?. Asian Political Science Review, 1(1), 19-31. http://dx.doi.org/10.12778/235108617X15452339029590

Thompson, P. B. (2018). Food production. Routledge Handbook of Development Ethics, 226.

Verma, A. (2007). Enhancing student learning in engineering technology programs? A case for physical simulations.

Vigliarolo, F. (2020). Economic phenomenology: fundamentals, principles and definition. Insights into Regional Development, 2(1), 418429. http://doi.org/10.9770/IRD.2020.2.1(2)

Virmani, A. (2004). India's economic growth: From socialist rate of growth to Bharatiya rate of growth: Working paper.

Wharton, J. (2017). Subsistence agriculture and economic development: Routledge. https://doi.org/10.4324/9781315130408

Wiggins, S., Sabates-Wheeler, R., \& Yaro, J. (2018). Rural Transitions, Economies and Rural-Urban Links.

Zhou, Y., \& Liu, Y. (2019). The geography of poverty: Review and research prospects. Journal of Rural Studies. https://doi.org/10.1016/j.jrurstud.2019.01.008

Sudawan SOMJAI is an Assistant Professor and Director of the Doctor of Philosophy Program in Development Administration, Suan Sunandha Rajabhat University, Thailand. Her research areas are Public and Private Administration, Development Administration, Leadership and Social Sciences Research and have many articles in these areas.

ORCID: https://orcid.org/0000-0002-8294-8166

Thitinan CHANKOSON is an Assistant Professor of Business Administration at the Faculty of Business Administration for Society, Srinakharinwirot University, Thailand. He holds a Doctor of Science in International Service Business Management from North Eastern University, Thailand. His research interests are service business management, aviation management, international business management, supply chain management, and tourism and hospitality industry.

ORCID: https://orcid.org/0000-0003-1855-678X

Kittisak JERMSITTIPARSER holds Ph.D. in Social Sciences from Kasetsart University, Thailand. He is currently a researcher at Chulalongkorn University Social Research Institute, a part-time researcher at Ton Duc Thang University, and the secretary general of Political Science Association of Kasetsart University. His areas of expertise are Political Science, Public and Business Administration, and Interdisciplinary Research in Social Sciences.

ORCID: https://orcid.org/0000-0003-3245-8705

Register for an ORCID ID:

https://orcid.org/register

Copyright (C) 2020 by author(s) and VsI Entrepreneurship and Sustainability Center

This work is licensed under the Creative Commons Attribution International License (CC BY).

http://creativecommons.org/licenses/by/4.0/

(c) (i) Open Access 